\title{
Future pattern of UK earth sciences starts to emerge
}

\section{London}

EARTH science departments in British universities will be classified into three types, with differing provision for teaching and research, if long-awaited recommendations announced last week are adopted. A comprehensive review of earth science departments, commissioned by the University Grants Committee (UGC), proposes the following classification of departments.

Type M. Medium to large departments providing teaching and research in mainstream earth sciences, including single honours courses. Some of these departments would run major items of equipment that would be made available to the wider community.

Type I. Medium to large departments or departmental groupings in which earth

\begin{tabular}{|c|c|c|}
\hline \multicolumn{3}{|c|}{ Earth sciences departments } \\
\hline Type M & Type 1 & Type J \\
\hline 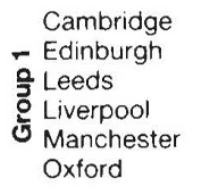 & $\begin{array}{l}\text { East Anglia } \\
\text { Lancaster }\end{array}$ & \\
\hline $\begin{array}{l}\text { Birmingham } \\
\text { Cardiff } \\
\text { N Durham } \\
\text { o. Glasgow } \\
\text { ò Leicester } \\
\text { BHBNC* } \\
\text { UCL/Birkbeck }\end{array}$ & $\begin{array}{l}\text { Aberystwyth } \\
\text { Imperial } \\
\text { Southampton }\end{array}$ & $\begin{array}{l}\text { Aberdeen } \\
\text { Keele } \\
\text { St Andrews }\end{array}$ \\
\hline $\begin{array}{l}\text { RHBNC, Royal } \\
\text { College. }\end{array}$ & Holloway and $\mathrm{E}$ & Bedford New \\
\hline \multicolumn{3}{|c|}{$\begin{array}{c}\text { Earth sciences provision within other } \\
\text { departments }\end{array}$} \\
\hline $\begin{array}{l}\text { Exeter } \\
\text { Hull } \\
\text { Newcastle† }\end{array}$ & $\begin{array}{l}\text { Nottingham } \\
\text { Sheffield }\end{array}$ & \\
\hline \multicolumn{3}{|c|}{$\begin{array}{l}\text { † Special collaborative arrangements will } \\
\text { apply between Newcastle and Durham. }\end{array}$} \\
\hline \multicolumn{3}{|c|}{ No on-site provision } \\
\hline $\begin{array}{l}\text { Aston } \\
\text { Dundee }\end{array}$ & $\begin{array}{l}\text { Strathclyde } \\
\text { Swansea }\end{array}$ & \\
\hline
\end{tabular}

scientists would contribute to interdisciplinary activity as well as mainstream earth sciences.

Type J. Small to medium departments or groups offering joint honours and service teaching, but without expensive earth science equipment on site.

Additionally, there would be institutions with no earth science departments as such, but which would provide teaching in some aspects of earth sciences located within an appropriate departments.

Within Types $M$ and I, departments seen as having particular strength and potential have been further categorized as
'Group 1', which will be given greater student numbers than other department of the same type (Group 2). It is recommended that the distinction between Groups 1 and 2 should not be permanent: the reorganization would be monitored at regular intervals by external visiting groups, which would inform the institutions and funding bodies of a department's progress, and would be empowered to recommend changes in status.

In the proposed scheme, all but two of the existing earth science departments have been classified (see table), with Reading and, more curiously, Bristol having yet to learn their fate.

The main surprises in the recommendations are that Imperial College has been classified as Type I rather than M, Swansea is to lose its department entirely, and Sheffield and Hull are to retain a provision for earth sciences only through other departments.

The national review committee was also asked to consider the Open University on the same basis as the institutions within the UGC's purview and decided that the university's earth science provision was equivalent to Type M, Group 1 .

While earth scientists are generally relieved that the model proposed by Professor Ron Oxburgh for a more closely defined three-tier system (see Nature 326, $813 ; 1987$ ) has been considerably watered down, and that the present model appears to incorporate a welcome degree of flexibility, there is concern that the level of concentration proposed in the new system will result in a net loss of opportunity for students to read earth sciences. Despite more widespread relief that the principal recommendations have been made, the review remains far from complete. Questions still need to be answered about the resources available for the whole reorganization and the allocation of resources between institutions. The joint UGC/NERC (Natural Environment Research Council) equipment rationalization committee, which will recommend where major pieces of apparatus should be housed, has yet to report.

A further uncertainty remains over the employment status of staff transferring between institutions. The government is presently trying to pass legislation that would abolish academic tenure for university staff taking up new appointments since last November, when the legislation was proposed. The Committee of Heads of University Geoscience Departments wrote to the government in January to try and obtain exemption for staff forced to move under the UGC reorganization, but still awaits a reply.
MoD's sums wrong?

THE British government has for years been overestimating the nation's total investment in research and development, according to a study by the Society for British Aerospace Industries (SBAC).

The study, which involved several of SBAC's larger member companies, concluded that Britain invests no more than 1.9 per cent of its gross domestic product in research and development, compared with the 2.3 per cent quoted in government statsitics. The study was undertaken when several defence manufacturers found it impossible to reconcile the value of work in their Ministry of Defence (MoD) contracts with the ministry's published expenditure on research and development. SBAC says that MoD accounting conventions, rather than being concerned with identifying funds it spends on research and development, are aimed at controlling the costs of projects. "But this can result in work which has little or no innovative content being categorized as $R$ and $D$ when it should not be counted as such", says SBAC.

S.H.

\section{Chinese prosper}

All Chinese scientists now have the right to get rich in their spare time. Following a successful pilot scheme, the Chinese government has decided to allow scientists and technical personnel to take second jobs for extra income. Scientists can now offer consultancy and advisory services to local farms and enterprises but they may have to share their fee with their main employer if his rights are affected.

V.R.

\section{Antarctica-on-Sea}

Already forced to deal with difficult logistics and tight budgets, the US National Science Foundation (NSF) Antarctic programme has a new problem on its hands: tourists. NSF estimates that 7,200 people will visit the Antarctic this year, double the number of government research and support staff supported by the 18 countries conducting research at the pole. NSF is talking to tour operators, hoping to minimize the impact on research, but it is accepted that the numbers of visitors is bound to grow.

J.P.

\section{Superhoax at $190 \mathrm{~K}$}

A REPORT in the London Times last Saturday that scientists at the Cambridge University Research Centre in Superconductivity had a $190-\mathrm{K}$ superconductor turns out to be the result of an undergraduate hoax. The success of the prank, which was perpetrated as part of the university's "rag week" celebrations, underlines the continuing popular interest in the race to higher superconducting transition temperatures.

L.G. 